The Effects of Cold Compress and Warm Compress on $\beta$-Endorphin Levels, IL-6 and TNF $\alpha$ among Adolescent with Dysmenorrhea

By Mukhoirotin Mukhoirotin 


\title{
The Effects of Cold Compress and Warm Compress on $\beta$-Endorphin Levels, IL-6 and TNF $\alpha$ among Adolescent with Dysmenorrhea
}

\author{
Mukhoirotin $^{1}$, Kurniawati ${ }^{1}$, Diah Ayu Fatmawati ${ }^{1}$ \\ 'Faculty of Health Science, University of Pesantren Tinggi Darul Ulum Jombang
}

\begin{abstract}
5on-pharmacological efforts to treat dysmenorrhoea are include cold compresses and warm compresses. The aim of this study was to determine the differences effect of cold compresses and warm compresses to $\beta$-Endorphin levels, IL-6 and TNF $\alpha$ among adolescents with dysmenorrhoea. The research was Post Test Only with Control Group. $\beta$ endorphin, IL- 6 and TNF $\alpha$ were measured by ELISA, then analyzed by Independent Sample T-Test. The average $\beta$ level of Endorphin in cold compress group was $143.03 \mathrm{pg} / \mathrm{ml}$, in warm compress group was $171.43 \mathrm{pg} / \mathrm{ml}$; the average IL6 level in cold compress group was $1352.60 \mathrm{pg} / \mathrm{ml}$, in warm compress group was $961.14 \mathrm{pg} / \mathrm{ml}$ and the average TNF $\alpha$ level in cold compress g1 up was 345.75 $\mathrm{pg} / \mathrm{ml}$, in warm compress group was $262.50 \mathrm{pg} / \mathrm{ml}$. The results of Independent Sample T-Test showed that there was no difference in $\beta$ levels of Endorphin IL-6 and TNF $\alpha$ in both of the warm and cold compresses group. Cold compress and warm compress can stimulate loose of Endorphin $\beta$ levels and regulate uterine hypercontractility during menstrual pain. Cold compress and warm compress can be used as an alternative to treat dysmenorrhoea.
\end{abstract}

Keywords: Cold compress, Warm compress, $\beta$-Endorphin levels, IL-6 levels, TNFa levels

\section{INTRODUCTION}

Dysmenorrhoea is a painful sensation with cramps sensation in the lower abdomen 17 nd commonly followed by sweating, tachycardia, headache, nausea, vomiting, diarrhea, and back pain before or during menstruation $^{(1-3)}$. The intensity of menstrual pain was varies from mild, moderate and severe ${ }^{(4)}$. Severe of dysmenorrhea give affects physical, psychological and social consequences ${ }^{(5)}$.

The prevalence of dysmenorrhoea in the world was varies from $37 \% 19090.1 \%$, in China there were $37 \%{ }^{(6)}, 55.5 \%-70 \%$ in 16 lolescents and young adults in Turkey ${ }^{(7-8)}, 60.9 \%$ of female medical students in King Abdulaziz University ${ }^{(9)}, 74.4 \%$ in teenage girls in

\footnotetext{
Corresponding Author:

Mukhoirotin

E-mail: mukhoirotin@fik.unipdu.ac.id

University of Pesantren Tinggi Darul Ulum Jombang, Indonesia
}

Ghana $^{(10)}, 74 \%-86.1 \%$ in Iran, $77.6 \%$ among University of Gondar Students, Northwestern Ethiopia ${ }^{(11)}, 90.1 \%$ among Jordanian University students ${ }^{(12)}$. In Indonesia an estimated $55 \%$ of women in productive age were experienced menstrual pain ${ }^{(13)}$. In East Java, the number of reproductive young women aged 10-24 is 56,598 and about $11565(1.31 \%)$ of those experienced dysmenorrhea and come to the obstetrics ${ }^{(14)}$.

15tors that can increase the risk of dysmenorrhoea are include age and age of younger menarche, longer duration of menstruation, menstrual volume ${ }^{(15-17)}$, low of BMI, smoking and alcoholism ${ }^{(16.18-19)}$, low social support, family history of dysmenorrhoea, high caffeine consumsion $^{(20)}$, depression, anxiety and stress $^{(7,21)}$. Primary dysmenorrhoea has a biochemical basis and doe to prostaglandin loose during menstruation. During the luteal and menstrual phases, prostaglandin F2alpha (PGF2- $\alpha$ ) were e 3 retion. Excessive release of PGF2- $\alpha$ will increase the amplitude and frequency of uterine contractions and causes vasospasm of the uterine arterioles, causing lower abdominal ischemia 
and cramps 14 and back pain ${ }^{(23)}$. Psychiatric factors also play a role in the occurrence of primary dysmenorrhea. Stress can increase the levels of vasopressin and catecholamines and it will make vasoconstriction and ischemia in cells ${ }^{(24)}$. Peripheral blood analysis in women with dysmenorrhoea shows excessive synthesis and concentration of oxytocin, PGF2-a, vasopressin, IL-6 and TNF(25-28). Dysmenorrhoea is a major cause of activities problem ${ }^{(29)}$ such as absent from work or school $^{(30-31)}$ and decreased quality of life ${ }^{(8,32-33)}$.

armacological interventions for dysmenorrhoea use nonsteroidal anti-inflammatory drugs (NSAIDs) and oral contraceptive. The side effects including dependence $^{(34-35)}$, diarrhea, abdominal pain, nausea ${ }^{(36)}$, kidney and liver complications, sleep disorders ${ }^{(37)}$, digestive disorders ${ }^{(38)}$. The failure rate of pharmacological treatment is $20-25 \%{ }^{(39)}$. Non-pharmacological interventions include cold and warm compress. Cold compress is ice therapy that can reduce prostaglandins which strengthens pain sensation and other subcutaneous at the injury place by inhibiting the inflammatory process. This is because cold compress can reduce blood flow to a part and reduce bleeding edema which is it cause analgesic effects by slowing the speed of nerve delivery so the pain impulses will less reach to the brain ${ }^{(40)}$. Warm compresses with hot jars cause conduction, where there is transfer of heat from the bladder into the body and it giving dilation for blood vessels and decreased muscle tension so that dysmenorrhoea pain will be reduced ${ }^{(41)}$. Skin stimulation causes the release of endor $13 \mathrm{~ns}$, thus blocking the transmission of pain stimuli ${ }^{(41)}$. The results of previous studies showed that Moxibustion can reduce the levels of PGF2 $\alpha$, oxytocin, vWF and increasing the levels of $\beta$-EP. The effect of cold and warm compress on $\beta$-Endorphin, IL-6 and TNF $\alpha$ has not been clearly known, so the researchers are interested to conducting the research about The Effects of Cold Compress and Warm Compress on $\beta$ - Endorphin levels, IL-6 and TNF $\alpha$ among Adolescents with Dysmenorrhoea.

\section{MATERIALS AND METHOD}

The design of this research was Pretest-Postest. The population were all students at FIK-Unipdu Jombang who experienced dysmenorrhoea. Sample size was 40 , selected by purposive sampling, then divided into cold compress group $(n=20)$ and warm compress group $(n=20)$. The instrument of data collection were thermometer, a hot jar and ice bag. Numeric Rating Scale used to 112 sure pain level. ELISA inderect method to measure the levels of $\beta$ Endorphin, IL- 6 and TNF $\alpha$ using the. Data were analyzed by T-Test.

\section{FINDINGS}

The intensity of dysmenorrhoea before giving cold compress were mostly at moderate. However, in warm compresses group were more than half of participant at severe level. Intensity of dysmenorrhoea after giving treatment in cold compresses group were mostly at mild, while in warm compresses group were mostly at moderate level. Homogeneity of variances test results showed that the intensity of dysmenorrhoea before and after giving treatment in both of groups were not have a significant difference.

Table 1. The differences of $\beta$-Endorphin levels, IL-6 and TNF $\alpha$ after giving intervention

\begin{tabular}{|c|c|c|c|c|}
\hline Variable & $\begin{array}{l}\text { Cold compress Mean- } \\
\text { (SD) }\end{array}$ & $\begin{array}{l}\text { 11/m compress } \\
\text { Mean-(SD) }\end{array}$ & $\begin{array}{l}\text { Mean Difference } \\
(95 \%-C I)\end{array}$ & $\mathbf{p}$ \\
\hline $\begin{array}{l}\beta \text {-Endorphin } \\
\text { IL-6 } \\
\text { TNF } \alpha\end{array}$ & $\begin{array}{l}143.03(3.97) \\
1352.60(3.57) \\
345.75(1.55)\end{array}$ & $\begin{array}{l}171.43(2.59) \\
961.14(3.79) \\
262.50(6.14)\end{array}$ & $\begin{array}{l}-28.40(-59.88=3.08) \\
39.46(-38.15-821.01) \\
83.25(-42.85-209.35)\end{array}$ & $\begin{array}{l}0.074 \\
0.070 \\
0.179\end{array}$ \\
\hline
\end{tabular}


There were no have significant differences levels of $\beta$ Endorphin, IL- 6 and TNF $\alpha$ after giving treatment

$\beta$-endorphin levels after giving cold and warm compress had no significant differences. Cold and warm compress are the techniques for cutaneous stimulation. Cutaneous stimulation is skin stimulation carried out to relieve pain, works by encouraging the release of endorphins, so it will block the transmission of pain stimuli $^{(41)}$. Changes in $\beta$-Endorphin levels can be explain 18 the basis of Opiate Endogenous theory, where opiate receptors in the brain and spinal cord were determine the central nervous system to activate morphine substances called endorphins and enkephalin when pain is received. This endogenous opiate can be stimulated by skin stimulation and muscles. These opioid receptors are located on peripheral sensory nerve extremity ${ }^{(42)}$.

Cold compress was given by using an ice bag filled with ice, compressed to the abdominal area for 6 minutes and a warm compress was given by using a bag filled with warm water at a temperature of $40-45 \mathrm{C}^{\circ}$ and compressed to the abdominal area for 20 minutes. The average $\beta$-endorphin level at cold compress group was $143.03 \mathrm{pg} / \mathrm{ml}$, the warm compress group was $171.43 \mathrm{pg} / \mathrm{ml}$. Giving cold and warm compresses can increase $\beta$-endorphin levels to relieve pain production. The higher of endorphins level make the level of pain at mild ${ }^{(43)}$. Endorphins inhibit fiber $\mathrm{C}$ in pre and post synapses and $\mathrm{A} \delta$ fibers in the dorsal horn and activate the larger of $A B$ (A-beta) sensory nerve fibers, thus blocking the pain signals when enter to spinal cord so the pain perception will decreases ${ }^{(44)}$. After intervention, the intensity of dysmenorrhea among respondents will decreased. This because of the release of $\beta$-endorphins levels that inhibit $C$ fiber and activate $A B$ sensory nerve fibers so it will inhibits the pain signals to spinal cord and decreased perception of pain. The result was in accordance with previous studies which showed that $\beta$-endorphin levels in primary dysmenorrhoea increased after moxibustion therapy. Moxibustion therapy is a warm moxa stimulation at Guanyuan, Shenque and Sanyinjiao acupuncture points, the treatment giving for 10-15 minutes a day during 7 days before menstruation in 3 menstrual cycles ${ }^{(45)}$.

IL-6 and TNF $\alpha$ levels had no difference. In primary dysmenorrhea, the level of genes expression of cytokine pro-inflammatory (IL1B, TNF, IL6 and IL8) at the first day of menstruation will significantly increases ${ }^{(28)}$. IL-6 functions to increase oxytocin secretion at the first day of menstruation ${ }^{(46)}$, where TNF $\alpha$ functions to increase prostaglandin and oxytocin at the first day of menstruation ${ }^{(47-48)}$. Increased prostaglandins and oxytocin have an impact to excessive uterine contractions, decrease endometrial blood flow and cause pain during menstruation $^{(28)}$.

Cold compresses provide physiological effects to reduce the inflammatory response, blood flow and edema, local pain ${ }^{(49)}$. Heat will stimulates the vascular reaction by increasing blood flow, resulting in delusions 10prostaglandins, bradykinin and histamine. Increasing blood flow also can increase oxygenation ${ }^{(39)}$. Local heat will give the abdomen to increasing gastrointestinal motility and relaxation to the uterus. Local heat is as effective as NSAIDs ${ }^{(50)}$. NSAIDs can reduce the accumulation of prostaglandins and reduce spasmo $9 \mathrm{c}$ contractions caused by prostaglandins and inhibit the activity of COX-2 and COX-1 enzymes ${ }^{(51)}$.

The results of previous studies showed that the giving of warm stimuli (moxibution) can regulate uterine hypercontractility during menstrual pain by set of the mediator pain level serum where occur the decreasing levels of PGF2 $\alpha$ serum and oxytocin ${ }^{(45)}$. The effect of moxibution treatment works like electroakupunctur ${ }^{(52)}$. Several studies have shown that electroacupuncture can reduce the expression of prostaglandin levels ${ }^{(53)}$, peripheral blood lymphocytes among rat as the samples with primary dysmenorrhoea ${ }^{(54)}$. T-cells are the main source of cytokine secretion (TNF, Interleukin, interferons $)^{(55)}$. Thus the cold compresses and warm compresses interventions can reduce pro-inflammatory cytokines IL- 6 and TNF $\alpha$.

\section{CONCLUSION AND RECOMMENDATION}

The results of this study showed that after giving warm and cold compresses in both group there were no differences in levels of $\beta$ Endorphin, IL-6 and TNF $\alpha$ among adolescents with dysmenorrhoea. Cold compresses and warm compresses can be used as an alternative treatment to dysmenorrhoea.

Ethical Clearance: Ethics Committee of Nursing Faculty, Airlangga University

Conflict of Interest: No 
8

Funding: Ministry of Research, Technology and Higher Education, Indonesia.

\section{REFERENCES}

1. Dawood MY. Primary Dysmenorrhea: Advances in Pathogenesis and Management. Obstet Gynecol. 2006. 108(2):428-441.

2. Kiran B, Sandozi T, Akila T, Chakraborty A, Meherban, Rani RJ. Study of the prevalence, severity and treatment of dysmenorrhea in medical and nursing students. International Journal of Pharma and Bio Sciences. 2012;3(1):161-170.

3. Mohamed EM. Epidemiology of dysmenorrhea among adolescent students. Life Science Journal. 2012;9(1):348-353.

4. Turk DC, Melzack R. Handbook of PainAssessment. . New York: Guilford Publications;2011.

5. Deb S, Raine-Fenning N. Dysmenorrhoea. Obstet, Gynaecol Reprod Med. 2008;18:294-299.

6. Zhou H, Yang Z, Group S. Prevalence of Dysmenorrhea in Female Students in a Chinese University: a Prospective Study. Health. 2010;2(4):311-314.

7. Ozerdogan N, Sayiner D, Ayranci U. Prevalence and Predictors of Dysmenorrhea among Students at a University in Turkey. Int J Gynaecol Obstet. 2009;107(1):39-43.

8. Unsal A, Ayranci U, Tozun M. Prevalence of Dysmenorrhea and Its Effect on Quality of Life among a Group of Female University Students. Ups JMed Sci. 2010;115(2):138-45.

9. Ibrahim NK, Alghamdi MS, Al-Shaibani AN, AlAmri FA, Alharbi HA, Al-Jadani AK, Alfaidi RA. Dysmenorrhea among female medical students in King Abdulaziz University: Prevalence, Predictors and outcome. Pak J Med Sci. 2015;31(6):13121317.

10. Gumanga S, Kwame A. Prevalence and Severity of Dysmenorrhea among some Adolescent Girls in a Secondary School iln Accra, Ghana. Postgraduate Medical Journal of Ghana. 2012;1(1).

11. Gebeyehu MB, Mekuria AB, Tefera YG, Andarge DA, Debay YB, Bejiga GS \& Gebresillassie BM. Prevalence, Impact, and Management Practice of Dysmenorrhea among University of Gondar Students, Northwestern Ethiopia: A Cross-Sectional
Study. International Journal of Reproductive Medicine. 2017.

12. Mukattash TL, Tahaineh L, AlRawi N, Jarab A, Hammad H, Nuseir K. Behaviors and Attitudes towards Dysmenorrhea; a Crosssectional Survey of 2,000 Jordanian University Students. Jordan Medical Journal. 2013;47(1):26-34.

13. Proverawati. Menarche: Menstruasi Pertama Penuh Makna (Menarche: First menstruation is meaningfull). Nuha Medika. Yogyakarta;2009.

14. BPS-Prov-Jatim. Jawa Timur dalam Angka Tahun 2015 (East Java in score in 2015). Surabaya: BPSProv-Jatim;2015.

15. In Ae Jang, Ming YK, Sa Ra L, Kyung AJ, Hye WC. Factors related to dysmenorrhea among Vietnamese and Vietnamese marriage immigrant women in South Korea. Obstet Gynecol Sci.2013;56(4):242248.

16. LattheP, Mignini L, Gray R, Hills R, Khan K. Factors P;redisposing Women to Chronic Pelvic Pain: Systematic Review. BMJ. 2006;332(7544):749-55.

17. MulunehAA, Nigussie TS, Gebreslasie KZ,Anteneh KT, Yohannes Z. Prevalence and Associated Factors of Dysmenorrhea among Secondary and Preparatory School Students in Debremarkos Town, North-West Ethiopia. BMC Women's Health.2018;18:57.

18. Perry M. Treatment Options for Dysmenorrhoea. Practice Nurs.2012;23:195-8.

19. Ju H, Jones M, Mishra GD. Smoking and Trajectories of Dysmenorrhoea among Young Australian Women. Tob Control.2016;25:195-202.

20. Faramarzi M, Salmalian H. Association of Psychologic and Nonpsychologic Factors with Primary Dysmenorrhea. Iran Red Crescent Med J. 2014;16(8):e16307.

21. Sahin N, Kasap B, Kirli U, Yeniceri N, Topal Y. Assessment of Anxiety-Depression Levels and Perceptions of Quality of Life in Adolescents with Dysmenorrhea. Reproductive Health.2018;15:13:1-7.

22. Lowdermilk, Perry, Cashion. Keperawatan Maternitas (Maternity Nursing). Elseiver;2013.

23. Varney. Buku Ajar Asuhan Kebidanan (Texbook of midwifery care). Jakarta:EGC; 2006.

24. Hillard PAJ. Dysmenorrhea. Pediatrics in Review. 
2006;27:64-71.

25. Liedman R, Hansson SR, Howe D, Igidbashian S, McLeod A. Reproductive Hormones in Plasma Over The Menstrual Cycle in Primary Dysmenorrhea Compared With Healthy Subjects. Gynecol Endocrinol. 2008;24:508-513.

26. Akernlund M. Involvement of Oxytocin and Vasopressin in the Pathophysiology of Preterm Labor and Primary Dysmenorrhea. Prog Brain Res. 2002;139:359-365.

27. Yeh ML, Chen HH, So EC, Liu CF. A Study of Serum Malondialdehyde and Interleukin-6 Levels In Young Women With Dysmenorrhea In Taiwan. Life Sciences. 2004;75:669-673

28. Ma H, Hong M, Duan J, Liu P, Fan X, et al. Altered Cytokine Gene Expression in Peripheral Blood Monocytes across the Menstrual Cycle in Primary Dysmenorrhea: A Case-Control Study. PLoS ONE.2013;8(2):e55200.

29. Marjoribanks J, Ayeleke RO, Farquhar C and Proctor M. Nonsteroidal anti-inflammatory drugs for dysmenorrhoea. Cochrane Database Syst Rev.2010;20(1):CD001751.

30. Wong LP, Khoo EM. Dysmenorrhea in a Multiethnic Population of Adolescent Asian Girls. Int J Gynaecol Obstet.2010;108(2):139-42.

31. Sharma N, Sagayaraj M, Sujatha B. Menstrual characteristics and prevalence of dysmenorrhea in college students. International Journal of Scientifc and Research Publications. 2014;4(10):1-6.

32. Ortiz MI. Primary Dysmenorrhea among Mexican University Students: Prevalence, Impact and Treatment. European Journal of Obstetrics $\&$ Gynecology and Reproductive Biology. 2010;152(1):73-7.

33. Gagua T, Tkeshelashvili B, Gagua D. Primary Dysmenorreahleading Problem of Adolescent Gynecology (review). Georgian Med News. 2012;207:7-14.

34. Gharloghi S, Torkzahrani S, Akbarzadeh AR, Heshmat R. The Effects of Acupressure on Severity of Primary Dysmenorrhea. Patient Prefer Adherence. 2012;6:137-42.

35. Chen MN, Chien LW, Liu CF. Acupuncture or Acupressure at the Sanyinjiao (SP6) Acupoint for theTreatment of Primary Dysmenorrhea: A meta-analysis. Evid Based Complement Alternat Med.2013:493038

36. Kashefi F, Ziyadlou S, Khajehei M, Ashraf AR, Fadaee AR, Jafari P. Effect of Acupressure at the Sanyinjiao Point on Primary Dysmenorrhea: A Randomized Controlled Trial. Complement Ther Clin Pract. 2010;16:198-202.

37. Wang YJ, Hsu CC, Yeh ML, Lin JG. Auricular Acupressure to Improve Menstrual Pain and Menstrual Distress and Heart Rate Variability for Primary Dysmenorrhea in Youth with Stress. Evid Based Complement Alternat Med. 2013:138537.

38. Nasehi M, Sehhatie F, Zamanzadeh V, Delazar A, Javadzadeh Y, Chongheralu BM. Comparison of the Effectiveness of Combination of Fennel Extract/ Vitamin E with Ibuprofen on the Pain Intensity in Students with Primary Dysmenorrhea. Iran J Nurs Midwifery Res.2013;18:355-9.

39. Navvabi Rigi et al. Comparing The Analgesic Effect of Heat Patch Containing Iron Chip and Ibuprofen for Primary Dysmenorrhea: A Randomized Controlled Trial. Biomed Central.2012.

40. Price AS, Wilson ML. Patofisiologi: Konsep Klinis Proses-Proses Poenyakit (clinical concept of disease process). Jakarta: EGC; 2005.

41. Potter \& Perry. Buku Ajar Fundamental Keperawatan (Textbook of fundamental of nursing) Jakarta:EGC;2010.

42. Rahayu D, Yunarsih. The transformation of $\beta$ Endorphyn level among primigravia inpartu $1^{\text {st }}$ level of active phase by using Comfort Food: Slow-Stroke Back Massage based on comfortable Kolcaba Theory in government hospital, Kediri. The Indonesian Journal of Helath Science. 2016;7(1): 1725.

43. Smeltzer SC, Bare BG. Textbook of Medical Surgical Nursing. Philadelphia: Lippincot Williams \& Wilkins; 2009.

44. Londhey VA. Pathophysiology of Pain. Suplement to Journal of The Association of Physicians of India. 2015.

45. Yang M, Chen X, Bo L, Lao L, Chen J, Yu S, Yu Z, Tang H, Yi L, Wu X, Yang J, Liang F. Moxibustion for Pain Relief in Patients With Primary Dysmenorrhea: A Randomized Controlled Trial. PLOS ONE. 2015;1-17. 
46. Rauk PN, Friebe-Hoffmann U, Winebrenner LD, Chiao JP. Interleukin-6 Up-Regulates the Oxytocin Receptor in Cultured Uterine Smooth Muscle Cells. Am J Reprod Immunol. 2015;45: 148-153.

47. Skarzynski DJ, Miyamoto Y, Okuda K. Production of Prostaglandin F(2alpha) by Cultured Bovine Endometrial Cells in Response to Tumor Necrosis Factor Alpha: Cell Type Specificity and Intracellular Mechanisms. Biol Reprod . 2000;62:1116-1120.

48. Thompson $M$, Barata da Silva $H$, Zielinska W, White TA, Bailey JP. TNF- $\alpha$-mediated Augmentation of Agonist-Induced Ca2+ Transients in Myometrial Cells. Am J Physiol Endocrinol Metab. 2004;287:E1142-1148.

49. Tamsuri. Konsep dan Penatalaksanaan Nyeri (Concept and treatment for pain). Jakarta: EGC; 2004.

50. Akin MD, Weingand KW, Hengehold DA, Goodale MB, Hinkle RT, Smith RP. Continuous low level topical heat in the treatment of dysmenorrhea. Obstet Gynecol. 2001;97:343-349.
51. Sahin I, Saracoglu F, Kurban Y, Turkkani B. Dysmenorrhea Treatment with a Single Daily Dose of Rofecoxib. International Journal of Gynecology and Obstetrics. 2003;83(3):285-291.

52. Lee I-S, Wallraven C, Kong J, Chang D-S, Lee H, Park H-J. When Pain is Not Only Pain: Inserting Needles into the Body Evokes Distinct RewardRelated Brain Responses in the Context Of A Treatment. Physiology \& behavior. 2015;140:14855.

53. Zhang HZ, Shan SL, Zhong-Xin WU, Wei XM. Effect of Electroacupuncture on SP and PGF2 in Serum of Dysmenorrhea Rats. Journal of Nanjing University of Traditional Chinese Medicine. 2014.

54. Ling-Yu LI, Yan P, Jin XF. Efect of Acupuncture at Zhibian Point on T Lymphocyte Subsets of Primary Dysmenorrhea Model Rats. Journal of Clinical Acupuncture Moxibustion. 2016.

55. Totsch SK, Sorge RE. Immune System Involvement In Specific Pain Conditions. Molecular Pain. 2017; 13:1-17. 
The Effects of Cold Compress and Warm Compress on $\beta$ Endorphin Levels, IL-6 and TNF $\alpha$ among Adolescent with Dysmenorrhea

ORIGINALITY REPORT

$10 \%$

SIMILARITY INDEX

PRIMARY SOURCES

1 www.mejfm.com Internet

20 words $-1 \%$

2 Ioannis Pilalas, Lazaros Tsalikis, Dimitris N. Tatakis. "Pre-restorative crown lengthening surgery outcomes:

14 words $-1 \%$ a systematic review", Journal of Clinical Periodontology, 2016 Crossref

3 citeseerx.ist.psu.edu Internet

14 words $-1 \%$

4 journals.plos.org Internet

13 words $-1 \%$

5 www.science.gov Internet

11 words $-1 \%$

6 Jin-min Lee, Kye-ha Kim. "Effect of near-infrared rays on female menstrual pain in Korea", Nursing \& Health

10 words $-1 \%$ Sciences, 2017 Crossref

7 Yeh, Mei-Ling, Yu-Ling Hung, Hsing-Hsia Chen, and 9 words $-<1 \%$ Yu-Jen Wang. "Auricular Acupressure for Pain Relief in Adolescents with Dysmenorrhea: A Placebo-Controlled Study", The Journal of Alternative and Complementary Medicine, 2012.

Crossref

8 media.neliti.com 
9 www.drugbank.ca

12 K. Müller. "In vitro cytokine production and phenotype expression by blood mononuclear 8 words $-<1 \%$ cellsfrom umbilical cords, children and adults", Pediatric Allergy and Immunology, 8/1996 Crossref

13 Hanan Elzeblawy Hassan, Wafaa Mostafa Ahmed 8 words $-<1 \%$ Gamel, Eman Ali Abd El Moaty Sheha, Mervat Amin Sayed, Ahmed Emad Eldin Arafa. "Menstrual disorders necessitating counseling among students in Beni-Suef University", Clinical Nursing Studies, 2019 Crossref

14 academic.oup.com Internet 8 words $-<1 \%$

15 dentisty.org Internet 8 words $-<1 \%$

16 pjms.com.pk Internet 8 words $-<1 \%$

17 www.nature.com Internet

8 words $-<1 \%$

18 "Encyclopedia of Pain", Springer Nature, 2013 Crossref

7 words $-<1 \%$ 
19 Heba A. Abu Helwa, Areen A. Mitaeb, Suha AlHamshri, Waleed M. Sweileh. "Prevalence of dysmenorrhea and predictors of its pain intensity among Palestinian female university students", BMC Women's Health, 2018 Crossref 